\title{
THE ROLE OF ABORISTS IN PROVIDING WILDLIFE HABITAT AND LANDSCAPE LINKAGES THROUGHOUT THE URBAN FOREST
}

\author{
by Julian A. Dunster
}

\begin{abstract}
In recent years, great advances have been made in arboriculture, but the main design professions, the general public, and some arborists still lack understanding about the ecological functions of trees for other organisms, and how these ecological functions and processes connect across larger landscapes. Consequently, many opportunities for the retention or creation of wildlife habitat in the urban forest are still being lost. Some of these opportunities are discussed, along with examples from British Columbia. A selection of references from related fields is included to provide a basis for further reading and understanding about landscape ecology, greenways, wildlife trees, and how arborists might integrate the principles from these fields into their practice.
\end{abstract}

Keywords. Urban forest; wildlife habitat; landscape ecology; linkages; wildlife trees.

Arborists play an important role in managing urban forests. Our prescriptions, management, and maintenance activities determine the structure and function of individual trees to stands of trees and entire forests in the larger landscape on public and private lands. Yet the contemporary focus is on the single tree, or on a group of trees in response to a single client. The situation is not helped by the pronounced division of responsibilities seen in most local government structures: the parks department looks after street trees and greenspaces, the planning department looks after new developments and redevelopments, and all too often, the engineering department works in isolation from everyone else.

Complicating this fragmented governance is an all-too-common lack of awareness, especially at the senior decision-making and political levels, about contemporary science and the need for interdisciplinary design approaches. How many members of the design professions such as engineering, architecture, planning, biology, and landscape architecture actually know what trees and wildlife require? Arborists would probably respond,
"Not many." Conversely, how many arborists understand the mindset of these other professions? Again, the likely answer is "Not many."

The profession of arboriculture has advanced considerably in recent years. We now have a better sense of how good pruning should be undertaken; we know more about roots, stress responses, good and bad retention, planting, and plant care practices. But all of this has focused on what the arboriculture profession considers to be the best means of maintaining a healthy tree. Less attention has been given to the role of these trees within an urban or rural ecosystem, and not all arborists may be aware of the contribution that trees make to the larger landscape in terms of ecosystem function and ecosystem processes. Consequently, we miss an important opportunity to advise the design professions about what other ecological functions a tree might provide.

In the field of landscape ecology, the notion of connectivity between larger patches or nodes of habitat is central to the function of a healthy system (Forman and Gordon 1986; Hodge 1995). Stream corridors and their associated riparian habitats, parks with forest components, and single trees or groups of trees on private and public lands all contribute to a mosaic of landscape connectivity. For many species of wildlife, connections between larger nodes of habitat may be essential to survival because fragmentation, and subsequent isolation of populations and their associated habitats, may lead to long-term loss of genetic flux, insufficient habitat area, and potential extirpation from the area, perhaps even extinction. A large body of literature is devoted to the theme of landscape linkages, which in the urban and rural context have been termed "greenways" (Hudson 1991; Labaree 1992; Smith and Hellmund 1993; Ministry of ELP 1995). 
Along similar lines, it is common to see landscapes formerly denuded of vegetation being restored as forests. This aspect is particularly evident in parts of Europe where lands formerly under agriculture or industrial uses are now abandoned. The literature on forest restoration, or recreation of forests, is plentiful and contains excellent guidance for arborists wishing to better understand the larger role of trees in a functional ecosystem (Forestry Commission 1990, 1991; Hodge 1995; Rodwell and Patterson 1995). The theme of ecosystem functions within urban forests is also well documented (Bradley 1995; Kollin 1994, 1995) and provides further insight about how trees provide so much more than shade, aesthetics, climate control, etc. The management of urban forests, especially small remnant patches, and the manner in which these can be used to create important patches of wildlife habitat (Agee 1995; Milligan Raedeke and Raedeke 1995) are integral to understanding the larger role that arborists could assume. Similarly, at the industrial scale of forest management, much new evidence is emerging about the manner in which wildlife habitat can be better integrated with commercial harvesting (Bradford et al. 1996).

Because of the rapid urban growth in many parts of British Columbia, the British Columbia Ministry of Environment issued an informative series of publications dealing with development and the environment. We now have detailed guidelines for developments next to streams and rivers and areas of specialized habitat (Chillibeck 1993; Ministry of ELP 1994), as well as guidelines for integrating development with greenways (Ministry of ELP 1995). Coupled with the emerging shift towards the creation of greenways and landscape linkages across entire municipalities or regional landscapes is the increasing need for a better understanding of trees. What makes them suitable for retention(Dunster 1995, 1996)? Which practices maximize the chances for long-term survival? What is the best approach for design and postconstruction management? When a broader view is taken, it is clear that arborists can assist other professionals in deciding how best to design and manage for sustainable urban forests and the creation of wildlife habitat.

\section{Trees as a Source of Wildlife Habitat}

Trees are a large and highly visible component of greenways. With the increasing focus on these landscape linkages, typically situated on a mix of public and private lands, arborists can anticipate a larger role in managing these systems. However, management of trees within greenway systems requires a focus beyond simple pruning and health care. In many cases, a dead or dying tree is just as important to the overall health of the ecosystem as the live and healthy trees.

The traditional response to dead or dying trees has been to remove them either because they are hazards, or to "tidy up" the landscape to avoid an anthropocentric perception of unkempt appearances. But this tidying-up approach can be ecologically damaging, and arborists need to better understand the role of dead or dying trees as a source of habitat. For example, large pieces of a tree, known in forest management as coarse woody debris, provide a source of food for many insects and fungi. Insects are a food source for the birds, which themselves help maintain insect populations at endemic levels. Small mammals find refuge and breeding areas in decayed logs, and it has been shown that dispersal of beneficial forest mycorrhizae is a direct function of small mammal populations and the dispersal of spores in their fecal pellets (Maser 1988; Machmer and Steeger 1993).

In industrial forest management, particularly in the United States and more recently in Canada, there has been a strong drive to manage the forests for more than just timber. Wildlife trees, defined as "tree[s] that provide ... present or future critical habitat for the maintenance or enhancement of wildlife" (Dunster and Dunster 1996) have value for many different species and are used for many different purposes including nesting, perching, feeding, or roosting. The species that use wildlife trees can be sorted into 5 categories (Maser 1988; Backhouse 1992; Wildlife Tree Comm. 1992):

1. Primary cavity excavators: Examples include woodpeckers, flickers and sapsuckers, chickadees, and nuthatches, all of 
which use their hard beaks to dig out holes in soft, decaying wood. These species make new cavities each year, leaving the old ones for other species to use.

2. Secondary cavity users: These species cannot excavate cavities by themselves, but use abandoned holes to nest and raise young, to store food, or simply as shelter. Examples are owls, tree swallows, bluebirds, and wood ducks, in addition to mammals such as martens, raccoons, flying squirrels, and deer mice.

3. Open nesters. These are the larger birds that require a place for heavy nests-typically birds of prey such as eagles, ospreys, or great blue herons. They can use dead or live trees but usually prefer trees with a broken top or flat crown that can support the nest and yet retain a clear field of view in all (or most) directions.

4. Other mammals: This category includes mammals such as bears (which often build dens in the hollow base of larger trees) and other large mammals such as caribou, which use the lichens growing on branches. Smaller mammals, such as bats and mice, find opportunities for shelter and nesting under loose bark and in other small cavities.

5. Amphibians: Amphibians use dead and dying trees as a shelter and brooding habitat, especially once the wood is in an advanced stage of decay and is soft and spongy enough to tunnel into, yet moist enough to protect the occupants.

In addition, decaying trees are often a source of nutrition at various levels of the food chain. For example, insects that attack dying trees often introduce fungal agents that help accelerate the decay processes. These insects become food for foraging birds, and fungi make the wood suitable for the cavity excavators. The use of wildlife trees in industrial forestry is well established (Thomas 1970; Bull et al. 1986; Morrison et al. 1986; Bradford et al. 1996; Parks et al. 1997). Trees with useful cavities for wildlife can be live, or can be partly or wholly dead, as shown in Figure 1.

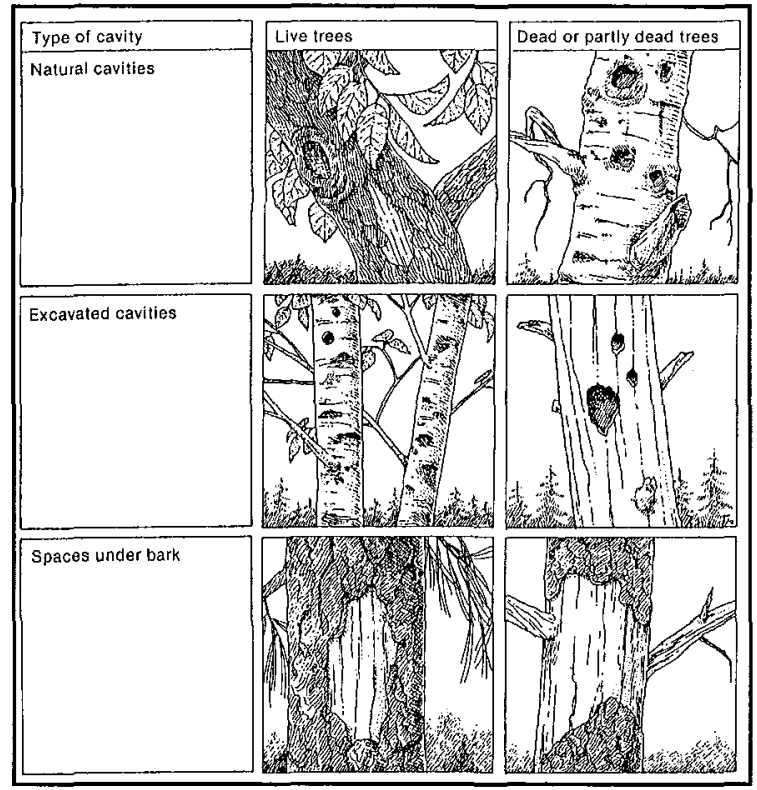

Figure 1. Cavities occur in many forms and have many uses for different species (from Thomas 1979).

In British Columbia, over 90 species are known to depend to some extent on wildlife trees, and about $18 \%$ of all bird species breed in the cavities of wildlife trees, including several rare and endangered species (Wildlife Tree Comm. 1992; Machmer and Steeger 1993). The establishment of the British Columbia Wildlife Tree Committee, jointly administered by the Ministry of Forests, the Ministry of Environment, Lands, and Parks, and the Workers Compensation Board, has given some credibility to the creation and retention of wildlife trees in industrial operations. This committee has established a training function to permit the identification and retention of trees considered necessary for wildlife (Wildlife Tree Comm. 1992), and the retention of such trees has now been extended into urban situations and greenways.

One of the simplest means of defining a landscape corridor (connection) on the ground is to retain the vegetation alongside creeks, streams, and rivers. In the British Columbia development

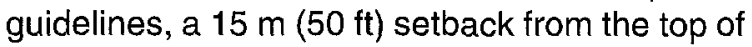
the bank is now considered a minimum amount 
of land to be left undeveloped. This setback zone protects the water body and retains a narrow area of riparian habitat, including trees. However, such a narrow band of remnant forest is quite often unsuitable for safe tree retention if it contains tall trees next to new residential developments (Dunster 1995). From a fisheries and environment viewpoint, trees provide shade for the water; cooler water holds higher oxygen concentrations, which in turn helps ensure fish survival. At the same time, litter from the trees provides nutrient inputs for the various insect fauna, and hence, a source of food for fish, and the tree roots stabilize the bank slopes. As a unit, the entire riparian zone provides a narrow band of habitat along which certain species of animal can travel, reasonably free of outside disturbance, although in a $30-\mathrm{m}(100-\mathrm{ft})$ band of forest, this is sometimes hard to achieve.

A common problem is that the retained trees, so greatly desired for environmental purposes, are often too tall, too isolated, and too hazardous to justify their retention. This often produces an immediate source of friction between those wanting the trees for their environmental benefits and those wanting them removed or treated to reduce the hazards. To reduce the leveis of friction, alternative approaches have been developed. The width of the setback zone design can be designed according to the development density, terrain, and vegetation types. Areas with young forest cover that can adapt to changed microclimatic and hydrological conditions resulting from adjacent developments may be more suitable for retention than areas covered with mature or semi-mature forest that may be unstable and often unable to adapt to the changed conditions fast enough, if at all. Such stands typically suffer decline once isolated and often fail to produce the benefits originally envisaged over longer periods of time.

To successfully implement an effective wildlife habitat plan, it is essential to have an interdisciplinary approach, in which experts in all fields can freely discuss ideas and requirements at the initial design stages-not at the last minute. In many cases, the planners can relax certain development requirements to permit a slight den- sity gain in one location in order to offset development losses due to environmental protection. In other cases, it may be necessary to carefully remove the unstable forest overstory (such as edge trees with no windfirmness, or suppressed trees with little or no rooting system) using specialized logging techniques involving a suspended lift of the felled trees to minimize ground disturbances. The relatively undisturbed ground is then replanted. In some instances, the material being removed is placed in a stable position on the ground and left to decay in place, thus ensuring no net loss of biomass from the site. Such techniques have been used successfully by the author; the coarse woody debris is important habitat and declines in place over time, while replanted trees develop very rapidly to create a new forest area that is better adapted to the new site conditions (Dunster 1995).

The creation of a good wildlife tree requires understanding its purpose. As a tree declines and dies, it provides habitat for a range of species. According to a a well-defined classification scheme for wildlife trees (snags) and logs on the ground, each stage of decomposition has its own particular uses for various species. The scheme shown in Figure 2 is typical.

A Class 1 wildlife tree is live and healthy. It may posses some small cavities that are a result of decay, not primary excavation. The crown foliage and branches are used for nesting, perching, or as territorial markers. If large lateral limbs are present, large birds of prey may nest or perch on them.

A Class 2 tree is at the initial stages of evident decline but still living. Dieback in the crown, usually as a result of internal decay (root rots or other fungal agents) has softened the center wood, leaving a hard outer shell. The tops or branches may be breaking off, and insect damage may be evident. Primary cavity excavators move in and new cavities appear annually. Foraging birds take advantage of the abundant insect life, while broken tops and limbs become nests and perching sites for raptors or other species such as owls.

A Class 3 tree is newly dead. The heartwood is usually hard, needles and twigs are still present, and the branches and bark are still intact. The roots are generally stable, but if root rot has killed 


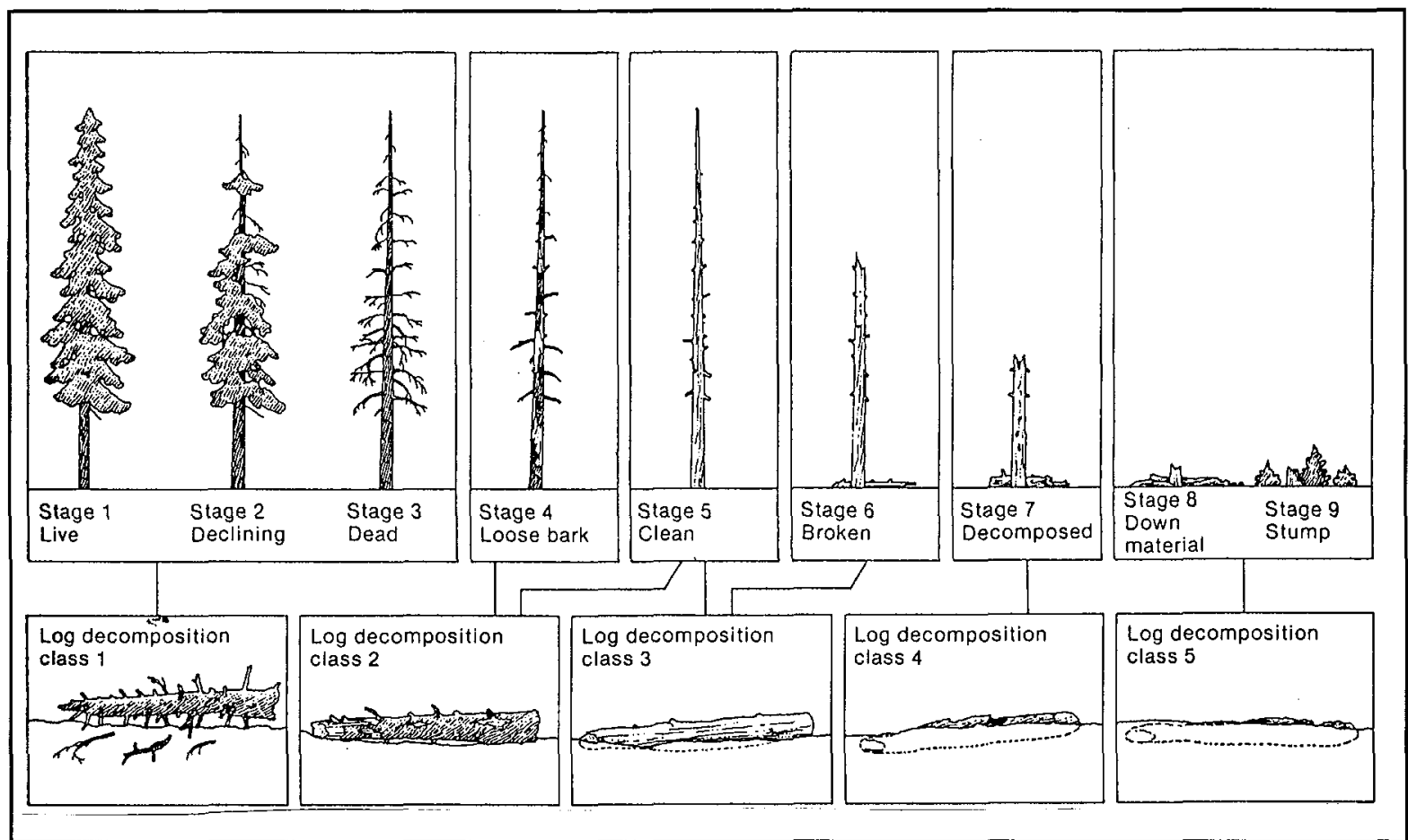

Figure 2. The classification of wildlife trees and fallen logs. The illustrations shows a conifer; similar stages would be seen in deciduous trees (from Thomas 1979).

the tree, this stability may be short lived. Class 3 trees are used by primary cavity excavators as well as secondary cavity users. The dead branches are used for hunting and hawking perches, roosts, and large nests. As insect populations increase, the tree will get more use from foragers.

A Class 4 tree has no needles or twigs, and at least $50 \%$ of the branches have been shed. The heartwood is still reasonably hard, but the bark is loose and the top may have fallen off. Cavity excavators are still active, but weaker species are now able to dig out smaller cavities. The abandoned cavities are actively used by secondary cavity users, and bats and other insect feeders are well established.

A Class 5 tree has decayed enough that it has spongy heartwood. Most branches are lost, the bark has fallen off, and internal decay is well advanced. On a larger tree, the roots may still be stable, but on smaller trees they may be approaching instability due to decay. Cavity users are still active, along with the insect feeders. As the wood gets softer, nesting and shelter opportunities for smaller mammals and amphibians increase.

A Class 6 tree has extensive internal decay and is starting to break up. The sapwood and heartwood starts to fall off from the upper trunk area, the smaller roots have decayed, and the larger roots are marginal. Cavity users no longer find it attractive habitat, but insect feeders, small mammals, and amphibians may increase.

A Class 7 to 8 tree is in the final stages of decay. A stub of the tree remains, showing extensive decay. A hard outer shell may remain, but the softer central wood is almost completely absent, and lateral roots are almost gone. At this stage, the tree is mainly used by amphibians, small mammals, and insect-feeding birds.

Finally, a Class 9 tree is a stump or small stub. It provides good habitat for salamanders, small mammals, and foraging birds, and may be used as a territorial marker or a drumming log for grouse. It is also a nutrient source within the ecosystem. 
Decomposed fallen trees have well-defined characteristics, and distinct species use the logs. Figure 2 shows the correlation between wildlife tree class and log decomposition class.

In a natural forested ecosystem, there will usually be an array of wildlife trees and fallen logs in many different stages of decay and use (Parks et al. 1997). In the managed ecosystem, many of these wildlife attributes may have been lost. With careful understanding of tree decay patterns and of the manner in which wildlife use trees, arborists can help foster environmental benefits and contribute to greater sustainability.

\section{Creating Wildlife Trees}

As a part of a provincial strategy to retain suitable wildlife habitat, foresters, biologists, and government officials in British Columbia have adopted the requirement for wildife trees. Wildlife trees can be found in several forms. The most obvious is the live tree in use by wildlife such as raptors nesting in the crown (eagles, ospreys, and herons). If these trees are in active use by certain species, they may be protected under wildlife laws; the arborist should know and recognize these trees and associated statutes. Whether a tree is in active use is not always easy to ascertain, but local sources of knowledge, such as nature clubs, local environmental organizations, and government authorities can help. In many cases, these trees will be designated as wildlife trees once they have been documented.

A second form of wildlife tree creation is taking an existing hazard tree, cutting it off at some height above the ground, and then leaving it to decay. In other cases, trees have been removed and then stuck back in the ground like giant posts (Bradford et al. 1996).

In British Columbia, it is now common to retain actively used wildlife trees, as well as to create new wildlife trees of varying heights. Some are little more than small logs pushed into the ground and will never serve as good raptor or woodpecker trees. Many large trees, deemed too tall and too unstable to safely retain, have been cut to a height at which they will not be a hazard to adjacent developments when such trees eventually fall down. These large trees, some of which are 15 to $20 \mathrm{~m}$ (50 to $66 \mathrm{ft}$ ) high, provide perching and nesting sites at the top and are already being explored by woodpeckers for nesting and forage. The cut top is notched and roughened with a saw to provide a sufficiently rough base for nest building. Under natural forces, the loss of entire tree tops is common throughout the Pacific Northwest and up into British Columbia. Douglas-fir and western hemlock are often seen as tall stumps with their entire crowns having been snapped off in heavy winds. Red alders and bigleaf maple, known for their propensity to decay from the top down, are common sites for cavity excavators.

Based on observations in the lower mainland of British Columbia, it seems to take about 3 to 4 years before coniferous trees are first colonized by woodpeckers. Thereafter, colonization by other species depends on rates of decay, but it seems likely that many of these wildlife trees will remain standing for 15 to 20 years before falling over. The hardwood species decay faster, and crown dieback and loss of the main scaffold takes place within about 10 years. In several sites, the most hazardous trees have been converted into wildlife trees of varying heights, and the area is replanted to recreate a young forest. Careful extraction of the tree tops, replanting, and retention of the understory where feasible, makes it possible to re-create habitat with good structural and biological diversity-one that can support a wide array of wildlife species for many years to come.

\section{Other Issues with Wildlife Trees}

In all of this work, safety must be considered. The current guidelines for wildlife tree retention in British Columbia stipulate the creation of no-work zones around the tree, based on its condition, the degree of lean, and the slopes. This is generally fairly easy to comply with, although in areas where a recreation trail passes close by, the manager of the area has to be fully aware of the snags and undertake routine checks to ensure that they pose no hazard to pedestrians. In some cases, it may require premature felling of the snags rather than letting them progress through to their natural fall-down point. When a large tree cannot be retained, or when larger branches must be re- 
moved, it is often feasible - and ecologically valuable-to leave the larger chunks (the coarse woody debris) on the ground to decay. In such cases, these larger logs should be stable, which usually requires all branches to be cut away so that the log sits right on the ground. It is also important to avoid using logs as bridges across creeks. Such a structure provides a tempting challenge to adventurous youngsters, but may bring with it a liability issue that should have been avoided. Similarly, logs on slopes are best left pointing downhill, rather than sitting across the slope. In the latter case, the log may roll and cause a hazard and associated liability.

Finally, there is always a question of how much clean-up should be undertaken. This will depend on the area, the species, and the goals of the management plan. In an urban situation, it is generally wise to clean up smaller branches and twigs to reduce the potential for fire hazards. This material can be chipped on site and the mulch blown back in a thin layer. Avoid large mulch piles: they might spontaneously ignite due to the heat of decomposition or will decay anaerobically and produce undesirable fermentation products. Evenly distributed thin layers decay rapidly and help stabilize the forest floor.

The other consideration is pest problems. For example, in British Columbia the Douglas-fir bark beetle is known to breed in the branch and twiggy material; cleaning and chipping this material reduces the chances of creating a bark beetle epidemic.

Rather than completely removing the whole tree, arborists can work with other professionals to determine a safe height for a wildlife tree. Perhaps only the top needs removing, or some of the higher branches, or maybe the whole tree has to come down but the larger logs can be left on site to decay slowly. Whatever the approach adopted, arborists have an opportunity to expand their own skills and play a useful role in helping create and maintain healthier urban forest ecosystems. The key to success lies in taking an interdisciplinary approach and understanding the role of trees in the ecosystem and how these functions can be incorporated into standard arboriculture practices. With this knowledge, arborists can actively promote these alternative practices and, over time, refine them. All of these small efforts will help to make our urban forests more sustainable.

\section{Literature Cited}

Agee, J.K. 1995. Management of greenbelts and forest remnants in urban forest landscapes, pp 128-138. In Bradley, G.A. (Ed.). Urban Forest Landscapes: Integrating Multidisciplinary Perspectives. University of Washington Press. Seattle, WA.

Backhouse, F. 1992. Wildlife Tree Management in British Columbia. Ministry of Environment, Lands, and Parks, Victoria BC.

Bradford, P., T. Manning, T., and B. l'Anson. (Eds.). 1996. Wildlife Tree/Stand-level Biodiversity Workshop Proceedings. Ministry of Forests and BC Environment, Victoria, BC.

Bradley, G.A. (Ed.). 1995. Urban Forest Landscapes: Integrating Multidisciplinary Perspectives. University of Washington Press, Seattle, WA.

Bull, E.L., C.G. Parks, and T.R. Torgersen. 1997. Trees and Logs Important to Wildlife in the Interior Columbia River Basin. Gen. tech. rept. PNW-GTR391. USDA Forest Service, Oregon.

Bull, E.L., J.W. Thomas, and K. Horn. 1986. Snag management on the national forests in the Pacific Northwest-1984. West. J. Appl. For. 1(2): 40-43.

Chillibeck, B. (Ed.). 1993. Land Development Guidelines for the Protection of Aquatic Habitat. Ministry of Environment, Lands, and Parks, Victoria, BC.

Dunster, J.A. 1995. Effective tree retention in new developments: An undisturbed landbase is the key to success, pp. 125-131. In Neely, D., and G. Watson (Eds.). Trees and Building Sites. International Society of Arboriculture, Savoy, IL.

Dunster, J.A. 1996. Hazard tree assessments: Developing a species profile for western hemlock. J. Arboric. 22(1):51-57.

Dunster, J.A., and K. Dunster. 1996. Dictionary of Natural Resource Management. UBC Press, Vancouver, BC.

Forestry Commission. 1990. Forest Nature Conservation Guidelines. HMSO, London.

Forestry Commission. 1991. Community Woodland Design Guidelines. HMSO, London.

Forman, R.T., and M. Gordon. 1986. Landscape Ecology. Wiley, New York, NY. 
Hodge, S.J. 1995. Creating and Managing Woodlands Around Towns. Forestry Commission Handbook 11. HMSO, London.

Hudson, W.E. (Ed.). 1991. Landscape Linkages and Biodiversity. Island Press, Washington, DC.

Kollin, C. (Ed.). 1994. Growing Greener Communities. Proceedings of the 6th National Urban Forest Conference. American Forests, Washington, DC.

Kollin, C. (Ed.). 1995. Inside Urban Ecosystems. Proceedings of the 7th National Urban Forest Conference. American Forests, Washington, DC.

Labaree, J.M. 1992. How Greenways Work: A Handbook on Ecology. National Park Service and Atlantic Centre for the Environment, Ipswich, MA.

Machmer, M.M., and C. Steeger. 1993. The Ecological Role of Wildlife Tree Users in Forest Ecosystems. First Draft. Ministry of Forests, Prince George, BC.

Maser, C. 1988. The Redesigned Forest. R. \& E. Mills, San Pedro, CA.

Milligan Raedeke, D.A., and K.J. Raedeke. 1995. Wildlife Habitat Design in Urban Forest Landscapes, pp 139-149. In Bradley, G.A. (Ed.). Urban Forest Landscapes: Integrating Multidisciplinary Perspectives. University of Washington Press, Seattle, WA.

Ministry of Environment, Lands, and Parks. 1994. Stream Stewardship: A Guide for Planners and Developers. MOELP, Victoria, BC.

Ministry of Environment, Lands, and Parks. 1995. Community Greenways: Linking Communities to Country, and People to Nature. MOELP, Victoria, BC.

Morrison, M.L., M.F. Dedon, M.G. Raphael, and M.P. Yoder-Williams. 1986. Snag requirements of cavitynestings birds: Are the USDA Forest Service guidelines being met? West. J. Appl. For. 1(2): 38-40.

Parks, C.G., E.L. Bull, and T.R. Torgersen. 1997. Field Guide for the Identifiaction of Snags and Logs in the Interior Columbia River Basin. Gen. tech. rept. PNW-GTR-390. USDA Forest Service, Oregon.
Rodwell, J., and G. Patterson. 1995. Creating New Native Woodlands. Forestry Commission Bulletin 112. HMSO, London.

Smith, D.S., and P.C. Hellmund. (Eds.). 1993. The Ecology of Greenways: Design and Function of Linear Conservation Areas. University of Minnesota Press, Minneapolis, MN

Thomas, J.W. (Ed.). 1979. Wildlife Habitats in Managed Forest: The Blue Mountains of Oregon and Washington. Agriculture Handbook No. 553. USDA Forest Service, Washington, DC.

Wildlife Tree Committee of British Columbia. 1992. Wildlife/Danger Tree Assessor's Course Work Book. Ministry of Forests; Ministry of Environment; Workers Compensation Board of British Columbia, Victoria, BC.

\section{Dunster \& Associates Environmental} Consultants Ltd.

P.O. Box 109

Bowen Island, $B C$

Canada VON $1 \mathrm{GO}$

Resumen. Los profesionistas de diseño, algunos arboristas y el público en general, carecen de un entendimiento acerca de las funciones ecológicas de los árboles para otros organismos, y cómo estas funciones y procesos ecológicos se conectan a través de grandes extensiones en el paisaje. Consecuentemente, se pierden muchas excelentes oportunidades para la creación y/o retención de hábitats de vida silvestre en el bosque urbano. Algunas de estas oportunidades son discutidas, junto con ejemplos de la Columbia Británica. Se incluye una selección de literatura de aspectos relacionados, para proveer las bases de lecturas adicionales y el entendimiento de la ecología del paisaje, corredores verdes, árboles silvestres y la manera como los arboristas pueden integrar estos principios dentro de sus prácticas. 